\title{
Christian Communications in Tanzania in the Year 2000
}

\author{
by Joseph G. Healey
}

Any predictions about Christian communications in Tanzania between now and the year 2000 must begin with the political realities. At present Tanzania is a one-party state; the Revolutionary Party (CCM) was founded in February, 1977. The basic political philosophy is Tanzanian Socialism following the principles of "Ujamaa" (Swahili for "Familyhood"). At present the Tanzanian Government encourages the growth of the Christian communications media.

But what will happen in 1990 or 2000 ? History shows that the political situation of African countries can change dramatically. And the Christian communications media are vitally affected. Just look at some of Tanzania's neighbours. The Ugandan Government has temporarily closed the publication of the Catholic daily "Munno" several times and has reduced the number of Church-produced radio and television programmes. The Ethiopian Government has taken over Radio Voice of the Gospel (RVOG). These examples have been repeated in other African countries as well.

But presuming that Tanzania continues with a one-party state and the philosophy of Tanzanian Socialism, one can predict that the general communications media picture in the year 2000 will look something like this:

Radio: At present radio is the only real mass medium with approximately 140.000 radio receivers in Tanzania. In the next 25 years the "transistor revolution" will reach all parts of the country including the rural areas. Radio will continue to be used mainly for educational purposes to promote various development policies adult education, agriculture, health, etc.

Television: The island of Zanzibar started Educational Color Television in 1973 on a very limited basis. But Mainland Tanzania has not yet introduced television because, as President Julius Nyerere has said, it would be an instrument for the elite rather than the masses of the Tanzanian people. Educational TV will be introduced gradually; it will be common in the cities but the technical problems of reaching rural areas will remain enormous.

Press: The development of newspapers, magazines and books is linked closely to literacy. The present rate of literacy is 30-35\% (the population being 15 million). While universal functional literacy is a top priority of the Tanzanian Government, many problems remain before it is achieved. Certainly in the next 25 years the Swahili press will expand greatly in Tanzania.

Audio-Visual: The next 25 years will witness the cassette revolution in Tanzania. Super 8 film will become an important educational tool. But how to "translate" the great technical advances in audio-visual media into every day use will be a

Joseph Healey M. M., M. A. war Gründer und erster Leiter des Kommunikationssekretariates bei der Vereinigung der Bischofskonferenzen im östlichen Afrika (AMECEA); er lebt jetzt in einem Ujamaa-Dorf der Diözese Rulenge, Tansania, als Missionar. 
continuing problem. Meanwhile "group media" and traditional African media of communications (singing, dancing, drumming, drama) will continue to flourish especially in rural areas.

All these communications media will be used to support and promote the Tanzanian Government's goals of freedom, unity and equality and the social and economic development of the country.

So it is within the "context" of these political realities that predictions can be made about Christian communications. Due to government policy (e.g. no Church-owned and run radio stations are permitted) and high costs (e. g. new printing plants are too costly) the Church's "institutional presence" will be small e.g. in terms of hardware. So the Church's future role lies more in production and software:

Radio (and eventually Television): The Church will continue to produce religious programmes (and some general interest programmes) for Radio Tanzania. If the Christian Churches train personnel in television now, these people will be ready when Educational Television is introduced in Mainland Tanzania.

Press: Kiongozi, the bi-monthly Catholic newspaper, has increased its circulation from 18,000 to 32,000 in the last four years. Prospects are good for even greater circulation and eventual self reliance. The regional newspapers and magazines such as Rumuli, Mwenge, Mlezi, Uhuru na Amani and Umoja face continuing technical problems e.g. spare parts, servicing of machines. The economic growth of Tanzania will determine if small, duplicated Church newsletters and mini-magazines are able to survive. Church book publishing will expand while high costs will hamper the growth of Church-run printing presses.

Audio-Visual: The possibilites are great in Tanzania but lack of trained personnel and production facilities make predictions difficult. Certainly the next 25 years will witness the increased use of cassettes and film in direct evangelization as well as group media. Mass production of cassette tapes could revolutionize the teaching of Bible, religious education and related subjects. While the Church will continue to use group media and traditional African media of communications, lack of coordination and planning will limit their widespread effectiveness.

So much of the future of Christian communications in Tanzania (and other African countries as well) depends on two factors:

1. Trained personnel.

2. Self-reliance.

It is difficult to predict if Christian Church leaders will adequately meet the challenges in these two areas. The Christian communicators will have a great opportunity to use the media for the whole development of the Tanzanian people. The growth potential of the Christian communications media will be greatly increased by its role in social and economic development.

Through the Office of Social Communications of AMECEA (Association of the Member Episcopal Conferences in Eastern Africa), the Christian communications media in Tanzania are closely linked to Kenya, Uganda, Malawi, Ethiopia and Zambia. Thus it is useful to conclude these predictions with the plan of action of the Office of Social Communications of AMECEA for the six countries in Eastern Africa: 


\section{Phase covering 1975-1980}

1. Concentration on specialized media training for carefully selected candidates with a view of producing university graduates who are professional leaders in Communications at the national level.

2. Decentralization: The role of the AMECEA Communications Office is becoming more and more that of an animator and advisor to the National Communications Offices. The National Offices have taken over the responsibility of organising and conducting Communications Workshops, Seminars and Meetings.

3. Production of communication material relevant to the local needs of the participants and the people in their area.

4. Devising ways of producing books, cassettes, records and plays as means of generating funds towards self-reliance.

5. Establishment of Diocesan Communications Centres.

6. Helping other students who are not from Church-related organizations to obtain training in communications.

\section{Phase covering 1981-on}

1. Giving Post-Graduate specialised training to key people in communications to lead communications planning, evaluation and research.

2. Establishment of book-publishing houses at the national level.

3. Formation of a regional film team.

4. Establishment of audio-visual centres.

5. Finding a Communications Consultant Agency overseas to advise on courses and scholarships.

6. Self-reliance.

7. Integration of Communications Education into the Major Seminaries and Religious Formation Syllabi.

\section{ZUSA M M N F A S S N G}

Wenn man annimmt, daß die politischen Verhältnisse in Tansania bis zum Jahre 2000 gleich bleiben, kann man die Kommunikationssituation folgendermaßen umschreiben: Schon jetzt ist das Radio das einzige wirkliche Massenmedium im Land. Die "Transistorrevolution" wird in 25 Jahren auch die letzten ländlichen Teile dieses Landes erreicht haben und hauptsächlich für Entwicklungszwecke eingesetzt werden. Fernsehen gibt es seit $1973 \mathrm{zwar}$ auf der Insel Sansibar, aber nicht auf dem Festland, wo es von Präsident Nyerere als ein Medium mehr für die Elite als für die Massen bezeichnet wurde. Bildungsfernsehen wird nur Schritt um Schritt und dann zunädhst für die Städte eingeführt werden. Die Entwidklung der Presse hängt insgesamt sehr von der Alphabetisierung ab; augenblidklich können 30 bis 35 Prozent der 15 Millionen Einwohner lesen. Es werden noch viele Probleme gelöst werden müssen, bis alle lesen und schreiben können. In jedem Fall wird sich die Presse in Suaheli in den nächsten 25 Jahren stärker entwidkeln. Für Kassetten im audio-visuellen Bereich wird eine Revolution stattfinden und 8-mm-Filme werden ein wichtiges Erziehungsmittel. Ständiges Problem wird es sein, wie die technisch entwickelten AV-Medien in den täglichen Gebrauch umgesetzt werden. Sog. Gruppenmedien und traditionelle afrikanische Kommunikations- 
formen werden vor allem in ländlichen Gegenden zunehmen. Die institutionelle Präsenz der Kirche in den technischen Einrichtungen des Landes wird auch in Zukunft wegen der Politik der Regierung und der hohen Kosten gering sein. Ihre Aufgabe liegt deshalb mehr im inhaltlichen Bereich: Die Kirchen werden fortfahren, Hörfunkprogramme zu produzieren. Wenn sie jetzt Fachkräfte für das Fernsehen ausbilden, werden diese zur Verfügung stehen, wenn das Fernsehen auf dem Festland eingeführt wird. Die 14täglich erscheinende katholische Zeitung "Kiongozi“ erhöhte in vier Jahren ihre Auflage von 18.000 auf 32.000. Die Aussidhten auf noch größere Auflage und wirtschaftliche Unabhängigkeit sind groß, während regionale Blätter technische Schwierigkeiten haben. Das wirtschaftliche Wachstum des Landes wird auch die Entwicklung dieser und vervielfältigter Blätter bestimmen. Die audio-visuellen Chancen der Kirche im Lande sind groß, aber es fehlt an ausgebildeten Kräften. Eine Massenproduktion von Kassetten könnte den Bibelunterricht und die religiöse Bildungsarbeit revolutionieren. Aber auch hier wird mangelnde Planung und Koordination die Effizienz behindern. Die Zukunft der christlichen Kommunikation in Tansania wie in ganz Afrika hängt von zwei Faktoren ab: von geschultem Personal und von wirtschaftlicher Unabhängigkeit. Es ist schwer vorauszusagen, ob die verantwortlichen Kirchenführer den Anforderungen in diesem Bereich entsprechen.

Uber das Kommunikationsbüro von AMECEA, der Vereinigung der Bischofskonferenzen des östlichen Afrika, ist Tansania eng mit Kenya, Uganda, Malawi, Sambia und Äthiopien verbunden. Deswegen ist der Aktionsplan dieses gemeinsamen Büros von einiger Bedeutung. Von 1975 bis 1980 sind vorgesehen: Spezialausbildung für künftige Kommunikationsdozenten und Planer; Dezentralisierung des zentralen Büros zugunsten nationaler Aktion und Verantwortung; Produktion von lokalen Kommunikationsangeboten; Hilfen für die Produktion der verschiedenen Medien und Ausbildung von Kommunikationskräften auch für den nichtkirchlichen Bereich. Ab 1981 sind vorgesehen:Universitätsausbildung für Leute in Schlüsselpositionen für Kommunikationsplanung, Evaluation und Forschung; Gründung eigener Verlagshäuser auf nationaler Ebene; Bildung eines regionalen Filmteams; Entwicklung audiovisueller Zentren; Kommunikationsberatung aus Übersee für Kurse und Stipendien; wirtsch iftliche Unabhängigkeit; Integration der Komnunikationserziehung in die großen Seminarien und deren Ausbildungspläne.

\section{RES U MÉ}

En Tanzanie, à condition que les rapports politiques dans le pays restent inchangés, la "révolution du transistor " va atteindre les dernières circonscriptions: principalement à des fins de développement. La télévision - présente à Zanzibar depuis 1973 - passe pour un medium d'élite et n'atteindra que lentement les villes du continent. Le développement de la presse dépend de l'alphabétisation. La presse Suaheli deviendra certainement plus forte. Les moyens audio-visuels auront une efficacité révolutionnaire en tant que moyens d'éducation. La présence de l'Eglise dans les institutions techniques sera à l'avenir minimale à cause de la politique gouvernementale et des frais élevés. Son devenir s'étend pour cela dans le domaine du contenu. Les Eglises continueront à produire des programmes de radio. Elles forment des techniciens, qualifiés dans le domaine de la télévision, qui seront présents quand la télévision sera introduite sur le continent. Le journal catholique continue à gagner en importance. Les feuilles régionales sont plus fortcment dépendantes de la croissance économique. Dans le domaine audio-visuel - pour l'exégèse et le travail de formation -, les chances de l'Eglise sont grandes. Mais l'avenir de la communication chrétienne en Tanzanie - de même que dans toute l'Afrique - dépend de deux facteurs: d'un personnel qualifié et de l'indépendance. Les chefs de l'Eglise correspondront-ils à ces demandes,

Ici, le plan d'action du bureau de communication de l'AMECEA, le rassemblement des conférences épiscopales en Afrique Orientale, a quelque importance. Il cherche à soutenir et à encourager le travail des mass media, aussi bien dans le domaine personnel que dans le domaine matériel. 


\section{R E S U M E N}

La "revolución del transistor" alcanzará en Tanzania - si se mantiene la situación política en el país - los últimos distritos: especialmente para fines de desarrollo. La televisión - en Zanzíbar desde 1973 - es un medio elitario y sólo lentamente se abre paso hacia las ciudades del interior. El desarrollo de la prensa depende de la alfabetización. La prensa Suaheli ganará terreno. Los medios audio-visuales (AV) actuarán revolucionariamente como instrumento educativo. La presencia de la Iglesia en las instituciones técnicas seguirá siendo mínima a causa de la política del gobierno y de los altos costos. Su misión se limita por ello al contenido. Las iglesias seguirán produciendo programas de radio. Si forma técnicos de televisión podrá emplearlos cuando la televisión llegue al interior. La prensa escrita católica es cada vez más importante. Los rotativos regionales dependen más del crecimiento económico. Las posibilidades de la Iglesia en el sector AV son grandes para la difusión de la Biblia y la educación. El futuro de la comunicación cristiana en Tanzania, como en toda Africa, depende de dos factores: del personal especializado y de la independencia. Responderá la jerarquía a este reto? En este contexto tiene importancia el plan de acción de la oficina para comunicación de la AMECEA, la asociación de las conferencias episcopales del Africa oriental. Trata de apoyar y promocionar los medios de comunicación en el sector personal y en el material. 